\title{
Peran Dukungan Sosial Keluarga dan Efikasi Diri Terhadap Tingkat Work-Life Balance Pada Mahasiswa Yang Bekerja Di Denpasar
}

\author{
Dewa Ayu Komang Triwijayanti dan Dewi Puri Astiti \\ Program Studi Sarjana Psikologi, Fakultas Kedokteran, Universitas Udayana \\ astiti22@yahoo.com
}

\begin{abstract}
Abstrak
Work-life balance merupakan hal yang berhubungan dengan kualitas kehidupan. Mahasiswa yang bekerja penting untuk mencapai work-life balance agar dapat memiliki kehidupan yang sejahtera. Pencapaian keseimbangan kehidupan dan kerja (work-life balance) dapat dipengaruhi oleh dua faktor yaitu faktor eksternal dan faktor internal. Faktor eksternal salah satunya ialah dukungan sosial terutama dukungan sosial keluarga. Keluarga sebagai lingkungan terdekat mampu mengurangi beban masalah yang dimiliki oleh mahasiswa. Faktor internal yang dapat memengaruhi salah satunya ialah efikasi diri. Efikasi diri yang baik mampu emmbantu mahasiswa untuk menghadapi masalah yang dihadapi. Penelitian ini bertujuan untuk melihat apakah peran dukungan sosial keluarga dan efikasi diri berperan secara signifikan terhadap tingkat work-life balance pada mahasiswa yang bekerja di Denpasar. Subjek dalam penelitian ini sebanyak 160 orang mahasiswa yang bekerja di Denpasar. Teknik sampling yang digunakan adalah purposive sampling. Alat ukur penelitian yang digunakan adalah skala dukungan sosial keluarga, efikasi diri, dan work-life balance. Hasil dari uji analisis regresi berganda menunjukkan nilai R2=0,660. Hal ini menunjukkan bahwa dukungan sosial keluarga dan efikasi diri berperan terhadap tingkat work-life balance pada mahasiswa sebesar $66 \%$. Nilai signifikansi sebesar 0,000 $(0<0,05)$ sehingga dapat disimpulkan bahwa dukungan sosial keluarga dan efikasi diri secara bersama-sama berperan dalam meningkatkan work-life balance pada mahasiswa yang bekerja di Denpasar.
\end{abstract}

Kata kunci: dukungan sosial keluarga, efikasi diri, mahasiswa yang bekerja, keseimbangan.

\begin{abstract}
Work-life balance has always been concern of relations to quality of life. College students who works needs to gain a work-life balance for their subjective well-being. Work-life balance can be achieved by internal factors and external factors. The external factors that has a high contribution is a social support especially from family. The family as the nearest environment can help the students for easing the burden and the overcoming problem. The internal factors is self-efficacy. Students that had role being a worker should have a good self-efficacy to facing and solve their problems. This research was conducted to see the role of family social support and self-efficacy towards the level of work-life balance of the college students who working in Denpasar. Subjects in this study were 160 college students who working in Denpasar. The sampling technique used in this research is purposive sampling. Measuring tools used in this research are the scale of family social support, self-efficacy, and work-life balance. The result of multiple regression analysis showed $\mathrm{R} 2=0,660$ it means that family social support and self efficacy variables give role to the level of worklife balance of $66 \%$. A significant value of $0,000(0<0,05)$ which means family social support and self efficacy variables contribute to the level of work-life balance of working students in Denpasar.
\end{abstract}

Key words: Family Social Support, Self-efficacy, Work-life balance, Working Student. 


\section{LATAR BELAKANG}

Fenomena kuliah sambil bekerja bukan merupakan hal yang baru di Indonesia, dapat dilihat dengan banyaknya universitas negeri maupun swasta yang membuka kelas khusus untuk karyawan. Pada umumnya, universitas yang membuka kelas bagi karyawan ini menyediakan waktu perkuliahan di luar waktu kerja, seperti kelas malam atau kelas Sabtu-Minggu. Sumber daya manusia merupakan salah satu faktor penting yang diperhatikan oleh perusahaan untuk mencapai tuntutan kerja (Artadi dalam Purwati, 2016). Lapangan pekerjaan menuntut para calon pelamar memiliki kemampuan untuk meningkatkan kualitas dan produktivitas perusahaan, baik dari segi pengalaman, soft skill, hard skill, maupun kompetensi pada bidang tertentu.

Bali, khususnya Kota Denpasar merupakan pusat kota yang memiliki banyak perusahaan atau organisasi yang menyediakan lapangan pekerjaan. Penelitian ini dilakukan di Denpasar dikarenakan daerah ini menjadi pusat kegiatan bisnis dan merupakan salah satu daerah yang memiliki pendapatan per kapita dan pertumbuhan yang tinggi di Provinsi Bali. Beberapa perusahaan maupun organisasi di Denpasar memiliki persyaratan bagi para pelamar yang dapat dipenuhi oleh mahasiswa seperti syarat minimum telah lulus SMA dan se-derajat. Tersedianya lapangan pekerjaan dan persyaratan melamar pekerjaan yang dapat dipenuhi oleh mahasiswa, menjadi sebuah fasilitas bagi para mahasiswa untuk mencari sumber penghasilan dalam membantu orangtua membiayai kuliah. Selain itu, dengan bekerja sambil kuliah mahasiswa memiliki pengalaman kerja yang dapat digunakan setelah lulus nanti.

Mahasiswa saat ini masuk dalam kategori generasi milenial. Generasi milenial merupakan generasi termuda dalam lingkungan kerja saat ini. Para generasi milenial merupakan individu yang lahir pada tahun 1982-1999. Twenge, Campbell, Hoffman, \& Lance (2010) menyebutkan bahwa dalam dunia kerja, para generasi milenial lebih tertarik terhadap pengembangan diri dan pencapaian keseimbangan dan kehidupan kerja (Work-Life Balance) dibanding mencari extrinsic reward seperti memperoleh reputasi yang baik maupun peningkatan ekonomi.

Individu harus memiliki keseimbangan antara kehidupan pribadi dan karir. Keseimbangan antara kehidupan pribadi dan karir ini biasa disebut dengan work-life balance. Work-life balance dapat diartikan sebagai minimnya konflik atau gangguan antara peran kerja dan non kerja yang dimiliki oleh seseorang dan menjadikan kehidupan pribadi dan pekerjaan menjadi seimbang (Frone, Russell, \& Cooper, 1992). Selain itu, work-life balance dapat menyebabkan individu memperoleh kesejahteraan dalam diri (subjective well-being) sehingga dapat mencapai kepuasan hidup (Gropel \& Kuhl, 2008).

Kuliah sambil bekerja memiliki dampak bagi seseorang baik segi positif maupun segi negatif. Dampak positif dari kuliah sambil bekerja diantaranya adalah mahasiswa dapat membantu orang tua dalam membiayai kuliah, memperoleh pengalaman kerja, serta kemandirian ekonomis sedangkan dampak negatif yang dialami oleh mahasiswa yakni kesulitan membagi waktu dan konsentrasi saat kuliah dan bekerja, kelelahan, penurunan prestasi akademik, mengalami keterlambatan kelulusan, dan dampak terburuk adalah dikeluarkan atau di-drop-out oleh universitas dan memilih untuk bekerja.

Pada dasarnya menjalani kuliah sambil bekerja menyebabkan individu memiliki beban peran yang berlebih, selain menjadi seorang akademisi, mahasiswa juga memiliki peran sebagai seorang karyawan. Beban peran yang berlebih dapat memengaruhi mahasiswa baik dalam segi akademis maupun non akademis. Menurut Yustrianthe (2008) kelebihan beban peran dalam satu waktu atau role overload akan terjadi jika seseorang mempunyai terlalu banyak pekerjaan yang harus diselesaikan di bawah tekanan waktu dan jadwal yang sangat ketat, serta tidak sesuai dengan kemampuan. Memiliki peran yang berlebih dalam satu waktu dapat menimbulkan konflik bagi individu baik dari dalam diri (internal) maupun diluar diri (eksternal) seperti terjadinya konflik peran, kelelahan fisik, stres, hingga depresi. Konflik yang dimiliki oleh mahasiswa menyebabkan sulitnya mencapai work-life balance.

Work-life balance dapat dicapai ketika individu tidak memiliki konflik antara kehidupan pribadi dan pekerjaannya (Frone, 1992). Studi pendahuluan yang dilakukan dalam penelitian ini terkait tingkat work-life balance pada 43 orang mahasiswa yang bekerja di Denpasar ditemukan bahwa adanya pengaruh motivasi baik secara internal maupun eksternal dalam meningkatkan work-life balance. Bentuk motivasi eksternal yang memiliki pengaruh terhadap keseimbangan kehidupan mahasiswa yang bekerja adalah dukungan sosial salah satunya adalah dukungan keluarga sedangkan bentuk motivasi internal yang dikembangkan oleh mahasiswa yakni keyakinan terhadap kemampuan diri atau efikasi diri (Triwijayanti, 2017).

Dukungan sosial yang diberikan oleh keluarga terhadap anggota keluarga dapat membantu mahasiswa untuk mencapai work-life balance. Kaplan dan Sadock (2010) menyatakan bahwa dukungan sosial keluarga adalah suatu bentuk hubungan interpersonal yang melindungi seseorang dari efek stres yang buruk yang dapat diberikan melalui pemberian dukungan informasional, dukungan penilaian, dukungan instrumental dan dukungan emosional. Selain dukungan sosial keluarga, work-life balance akan tercapai apabila individu mengembangkan faktor yang ada didalam dirinya. Faktor dalam diri tersebut meliputi aspek kepribadian individu salah satunya mencakup efikasi diri.

Bandura (1986) menjelaskan bahwa individu yang merasa dirinya memiliki efikasi yang baik dalam bertindak dan berpikir, merasa berbeda dengan individu lain yang tidak memiliki efikasi diri yang baik. Individu yang memiliki efikasi diri yang baik memiliki pandangan tersendiri terhadap masa depan. Semakin tinggi tingkat efikasi diri yang dimiliki oleh individu maka pola pikir dan perilaku individu akan mengarah kepada sikap optimis, sebaliknya semakin rendah efikasi diri individu maka pola pikir dan perilaku individu mengarah pada sikap yang pesimis. Memiliki sikap yang optimis dapat menyebabkan individu memiliki kepuasan dan motivasi kerja yang baik akan memengaruhi keseimbangan hidup individu baik dalam kegiatan bekerja maupun kegiatan pribadinya. 
Semakin majunya era globalisasi saat ini, konsep work-life balance penting untuk diteliti karena semakin tinggi tingkat kompetitif setiap individu dalam menyeimbangkan karir dan kehidupan personalnya. Berdasarkan pemaparan latar belakang di atas, maka penelitian ini dilakukan untuk mengetahui peran dukungan sosial keluarga dan efikasi diri terhadap tingkat work-life balance pada mahasiswa yang bekerja di Denpasar.

\section{METODE PENELITIAN}

\section{Variabel dan Definisi Operasional}

Variabel bebas dalam penelitian ini adalah dukungan sosial keluarga dan efikasi diri. Variabel tergantung yang digunakan dalam penelitian ini adalah work-life balance. Definisi operasional masing-masing variabel dalam penelitian ini adalah

\section{Dukungan Sosial Keluarga}

Dukungan sosial keluarga dalam penelitian ini dilihat dari pemberian dukungan dari seluruh anggota keluarga dalam bentuk dukungan emosional, informatif, evaluatif, dan instrumental. Taraf dukungan sosial keluarga dalam penelitian ini diukur dengan skala dukungan sosial keluarga. Semakin tinggi skor total maka semakin tinggi taraf dukungan sosial keluarga.

Efikasi Diri

Efikasi diri dalam penelitian ini dilihat dari sikap yang dimiliki oleh mahasiswa dalam bentuk yakin terhadap kemampuan diri, optimis, objektif, bertanggung jawab, rasional dan realistis. Taraf efikasi diri dalam penelitian ini diukur menggunakan skala efikasi diri. sehingga semakin tinggi skor total maka semakin tinggi taraf efikasi diri.

Work-life balance

Work-life balance dalam penelitian ini dilihat dari keadaan seimbang antara tuntutan dan kepuasan seseorang terhadap karir dan kehidupan pribadinya baik dari keseimbangan waktu, keseimbangan peran, dan keseimbangan kepuasan. Taraf work-life balance diukur menggunakan skala work-life balance. Semakin tinggi skor total maka semakin tinggi taraf work-life balance.

\section{Subjek}

Populasi pada penelitian ini adalah mahasiswa yang bekerja di Denpasar. Subjek dalam penelitian ini memiliki karakteristik sebagai berikut, mahasiswa yang masih aktif dan terdaftar di universitas masing-masing, usia subjek berkisar antara $18-25$ tahun, telah bekerja minimal 1 tahun, jam kerja minimal 20 jam dalam satu minggu, bekerja di Denpasar, dan bertempat tinggal di Bali

Metode pengambilan sampel dalam penelitian ini menggunakan metode non-probability sampling dengan teknik purposive sampling. Teknik purposive sampling merupakan pemilihan sampel dengan maksud atau tujuan tertentu berdasarkan karakteristik subjek yang telah ditentukan (Sugiyono, 2014). Penentuan jumlah sampel dalam penelitian ini menggunakan rumus yang dijelaskan oleh Field (2009) yakni VB x 15. Penggunaan rumus tersebut dilakukan karena jumlah populasi dalam penelitian ini tidak diketahui.
Berdasarkan rumus tersebut, maka jumlah minimal sampel yang diperlukan dalam penelitian ini adalah 30 subjek.

\section{Tempat dan Waktu Penelitian}

Pengambilan data dilakukan sebanyak tiga kali yakni pada 17 November 2017, 17 Januari 2018, dan 12 Mei 2018 dengan menyebar skala kepada mahasiswa yang bekerja di Denpasar. Skala yang disebar oleh peneliti terdiri atas informed consent, skala dukungan sosial keluarga, dukungan efikasi diri, dan skala work-life balance. Jumlah kuesioner yang disebarkan

sebanyak 175, namun hanya 160 kuesioner yang memenuhi syarat untuk dapat dilakukan analisis data.

\section{Alat Ukur}

Terdapat tiga skala yang digunakan dalam penelitian iniyaitu skala dukungan sosial keluarga, skala efikasi diri, dan skala work-life balance. Ketiga skala tersebut menggunakan jenis skala Likert yang terdiri atas empat pilihan jawaban yaitu sangat setuju (ss), setuju (s), tidak setuju (ts), dan sangat tidak setuju (sts). Skala dukungan sosial keluarga disusun berdasarkan empat kategori utama oleh House (1987). Skala efikasi diri disusun berdasarkan aspek - aspek efikasi diri yang dikemukakan oleh Lauster (1988). Skala work-life balance disusun berdasarkan aspek-aspek work-life balance yang dikemukakan oleh Greenhaus (2003).

Menurut Sugiyono (2014) alat ukur yang valid dan reliabel adalah syarat untuk mampu menghasilkan data yang akurat. Pengukuran terhadap validitas isi dalam penelitian ini dilakukan menggunakan teknik expert judgement. Proses pengujian validitas konstruk dilakukan dengan melakukan seleksi pada aitem skala berdasarkan korelasi aitem-total. Koefisien korelasi aitem- total sama dengan atau lebih besar dari 0,30 dianggap sudah memuaskan. Pengukuran reliabilitas dalam penelitian ini menggunakan Cronbach Alpha. Reliabilitas skala dapat dikatakan baik apabila memiliki nilai koefisien alpha $(\alpha)$ lebih besar dari 0,60 .

Hasil uji validitas skala dukungan sosial keluarga memiliki koefisien korelasi aitem total berkisar antara 0,407 sampai 0,584. Hasil uji reliabilitas skala dukungan sosial keluarga dengan menggunakan teknik Alpha Cronbach menunjukkan koefisien alpha $(\alpha)$ adalah 0,735 artinya bahwa skala ini mampu mencerminkan 73,5\% variasi skor murni subjek. Hasil uji validitas skala efikasi diri memiliki nilai koefisien aitem total yang valid berkisar antara 0,306 sampai 0,562. Hasil uji reliabilitas skala efikasi diri dengan menggunakan teknik Alpha Cronbach menunjukkan koefisien alpha $(\alpha)$ adalah 0,801 artinya skala ini mampu mencerminkan $80,1 \%$ variasi skor murni subjek. Hasil uji validitas skala work-life balance memiliki nilai koefisien aitem total yang valid berkisar antara 0,316 sampai 0,741. Hasil uji reliabilitas skala work-life Balance (WLB) dengan menggunakan teknik Alpha Cronbach menunjukkan koefisien alpha $(\alpha)$ adalah 0,934 artinya skala ini mampu mencerminkan 93,4\% variasi skor murni subjek.

\section{Teknik Analisis Data}

Uji asumsi dibutuhkan dalam menguji sebuah hipotesis penelitian. Teknik analisis data yang digunakan dalam 
penelitian ini untuk menguji hipotesis penelitian adalah uji normalitas, uji linearitas, dan uji multikolinearitas. Uji normalitas data penelitian dilakukan dengan uji Saphiro- Wilk. Uji linearitas data penelitian dilakukan dengan menggunakan analisis Compare Mean kemudian di uji dengan Test of Linearity. Uji multikolinearitas dalam penelitian ini dilakukan dengan melihat nilai Variance Inflation Factors (VIF) dan nilai Tolerance. Pengujian hipotesis dalam penelitian ini dapat dilakukan apabila seluruh uji asumsi terpenuhi. Uji hipotesis dalam penelitian ini menggunakan teknik analisis regresi berganda. Analisis data dalam penelitian ini dilakukan dengan bantuan perangkat lunak SPSS 24.0 release for Windows.

\section{HASIL PENELITIAN}

\section{Karakteristik Subjek}

Subjek dalam penelitian ini berjumlah 160 yang memiliki rentang usia 19-24 tahun dengan mayoritas subjek berusia 2122 tahun yakni sebesar 35,6\%. Sebagian besar subjek penelitian masih menempuh semester 8 pada masa perkuliahan yakni sebesar 44,4\%. Mayoritas subjek memiliki jam kerja selama 8 jam dalam satu hari yakni sebesar 46,9\%.

\section{Deskripsi Data Penelitian}

Hasil deskripsi data penelitian yaitu dukungan sosial keluarga, efikasi diri, dan work-life balance dapat dilihat pada table 1 . (deskripsi data penelitian. terlampir). Hasil deskripsi pada tabel 1 menunjukkan bahwa variabel dukunagn sosial keluarga memiliki nilai mean empiris yang berbeda secara signifikan terhadap mean teoretisnya. Hal ini dapat dilihat dari nilai probabilitas uji one-sample $t$ test sebesar $0,000(p<\alpha)$. Nilai mean empiris yang lebih besar dari mean teoretis mengindikasikan bahwa subjek memiliki tingkat dukungan sosial keluarga yang cenderung tinggi. Tabel 1 juga menunjukkan bahwa variabel efikasi diri memiliki nilai mean empiris yang berbeda secara signifikan terhadap mean teoretisnya. Hal ini dapat dilihat dari nilai probabilitas uji onesample $\mathrm{t}$ test sebesar $0,000(\mathrm{p}<\alpha)$. Nilai mean empiris yang lebih besar dari mean teoretis mengindikasikan bahwa subjek memiliki tingkat efikasi diri yang cenderung tinggi. Selanjutnya, pada tabel 1 juga menunjukan bahwa variabel work-life balance memiliki nilai mean empiris yang berbeda secara signifikan terhadap mean teoretisnya. Hal ini dapat dilihat dari nilai probabilitas uji one sample $\mathrm{t}$ test sebesar $0,000(p<\alpha)$. Nilai mean empiris yang lebih besar mengindikasikan bahwa subjek memiliki tingkat work-life balance yang cenderung tinggi.

\section{Uji Asumsi}

\section{Uji Normalitas}

Uji normalitas bertujuan untuk melihat apakah data yang menjadi variabel penelitian berdistribusi normal. Uji normalitas digunakan dengan menggunakan uji Shapiro-Wilk test. Data dikatakan normal apabila nilai signifikansi lebih besar dari $0,05(\mathrm{p}>0,05)$ sedangkan, jika probabilitas data lebih kecil dari 0.05 , berarti data tidak berdistribusi normal (Sugiyono, 2014).

Berdasarkan hasil uji normalitas pada tabel 2 (uji normalitas data penelitian. terlampir) menunjukkan bahwa sebaran data pada variabel dukungan sosial keluarga tidak berdistribusi normal dengan nilai Shapiro-Wilk 0,948 dan signifikansi $0,000(\mathrm{p}<0,05)$. Sebaran data pada variabel efikasi diri yang ditunjukkan pada tabel 2 tidak berdistribusi normal dengan nilai Shapiro-Wilk 0,882 dan signifikansi $0,000 \quad(\mathrm{p}<0,05)$. Sebaran data pada variabel work-life balance yang ditunjukkan pada tabel 2 berdistribusi normal dengan nilai Shapiro-Wilk 0,989 dan signifikansi 0,242 (p>0,05).

Uji Linearitas

Uji Linearitas bertujuan untuk mengetahui adanya hubungan linear antara variabel bebas dan variabel tergantung (Ghozali, 2005). Data dikatakan linier apabila koefisien deviation from linearity $>0,05$, sedangkan data dikatakan memiliki hubungan yang linier apabila nilai signifikansi linearity kurang dari 0,05 $(\mathrm{p}<0,05)$.

Berdasarkan hasil uji linearitas pada tabel 3 (hasil uji linearitas data penelitian. terlampir) menunjukkan bahwa terdapat hubungan yang linear antara variabel dukungan sosial keluarga dan work-life balance, serta antara variabel efikasi diri dengan work-life balance. Hal ini ditunjukkan melalui nilai taraf signifikansi linearity antara variabel dukungan sosial keluarga dan work-life balance yaitu sebesar 0,000 $(\mathrm{p}<0,05)$ dan memiliki nilai taraf signifikansi deviation from linearity sebesar $0,855(\mathrm{p}>0,05)$, serta nilai taraf signifikansi linearity antara variabel efikasi diri dengan work-life balance yaitu sebesar $0,000 \quad(\mathrm{p}<0,05)$ dan memiliki nilai taraf signifikansi Deviation from Linearity sebesar 0,464 ( $>>0,05)$.

\section{Uji Multikolinearitas}

Uji multikolinearitas digunakan untuk mengetahui apakah terdapat korelasi yang tinggi antarvariabel bebas (Ghozali, 2015). Data dikatakan tidak memiliki multikolinearitas jika nilai VIF (Variance Inflation Factor) dibawah $10(<10)$ dan nilai Colinearity Tolerance diatas $0,1(>0,1)$ (Ghozali, 2015). Berdasarkan hasil uji multikolinearitas pada tabel 4 (hasil uji multikolienaritas data penelitian. terlampir) menunjukkan bahwa kedua variabel penelitian yaitu dukungan sosial keluarga dan efikasi diri tidak terjadi multikolinearitas atau tidak terjadi korelasi. Hal ini ditunjukkan berdasarkan pada variabel kontrol diri dan pola asuh autoritatif yang sama-sama menunjukkan nilai Tolerance sebesar 0,996 (Tolerance>0,1) dan nilai Variance Inflation Factor (VIF) sebesar 1,004 $(\mathrm{VIF}<10)$.

\section{Uji Hipotesis}

Uji hipotesis statistik yang digunakan dalam penelitian ini adalah uji regresi berganda (Multiple Regression). Analisis regresi berganda dilakukan agar peneliti mengetahui hubungan antarvariabel secara keseluruhan dan melihat arah dari ketiga variabel yang telah ditentukan. Metode analisis regresi berganda dapat dilakukan apabila terdapat satu variabel terikat dan dua variabel bebas (Santoso, 2014).

Berdasarkan hasil pada tabel 5 (uji regresi berganda. terlampir) menunjukkan nilai $\mathrm{R}$ sebesar 0,812, hal ini menunjukkan bahwa terdapat peran yang kuat antara variabel bebas yaitu dukungan sosial keluarga dan efikasi diri terhadap variabel terikat yaitu work-life balance. Nilai koefisien determinasi (R Square) sebesar 0,660 menunjukkan variabel bebas memiliki peran sebesar $66 \%$ terhadap variabel terikat, 
sedangkan $34 \%$ dipengaruhi oleh faktor lain yang tidak diteliti dalam penelitian ini.

Hasil uji regresi berganda signifikansi nilai $F$ pada tabel 6 (hasil uji regeresi berganda signifikansi nilai f. terlampi) diperoleh hasil signifikansi sebesar 0,000 ( $\mathrm{p}<0,05)$. Artinya, model regresi ini dapat digunakan untuk memprediksi worklife balance. Berdasarkan hasil tersebut, dapat disimpulkan bahwa dukungan sosial keluarga dan efikasi diri sama-sama berperan terhadap work-life balance.

Berdasarkan hasil pada tabel 7 (hasil uji regresi berganda nilai koefisien beta-. terlampir) dukungan sosial keluarga memiliki nilai koefisien beta terstandarisasi sebesar 0,803 dengan nilai t sebesar 17,217 dan signifikansi sebesar 0,000 ( $\mathrm{p}<0,05)$. Hasil tersebut menunjukkan bahwa dukungan sosial memiliki peran yang signifikan terhadap work-life balance. Variabel efikasi diri memiliki nilai koefisien beta terstandarisasi sebesar $-0,079$, nilai t sebesar $-1,683$, dan nilai signifikansi sebesar 0,047 $(\mathrm{p}<0,05)$. Variabel efikasi diri juga dapat berperan secara mandiri untuk dapat meningkatkan work-life balance. Berdasarkan hasil diatas dapat disimpulkan bahwa dukungan sosial keluarga dan efikasi diri memiliki peran untuk meningkatkan work-life balance namun, dukungan sosial keluarga memiliki pengaruh yang lebih besar dibanding efikasi diri.

Hasil uji regresi berganda pada tabel 7 dapat digunakan untuk memprediksi tingkat work- life balance dari masing-masing subjek penelitian dengan melihat persamaan garis regresi sebagai berikut :

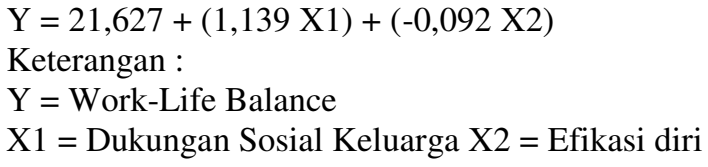

a. Konstanta sebesar 21,627 menyatakan jika tidak ada penambahan atau peningkatan skor pada dukungan sosial keluarga maupun efikasi diri maka tingkat worklife balance sebesar 21,267.

b. Koefisien regresi X1 sebesar 1,139 menyatakan setiap terdapat penambahan atau peningkatan satuan skor subjek pada variabel dukungan sosial keluarga, maka akan terjadi peningkatan work-life balance sebesar 1,139 .

c. Koefisien regresi X2 sebesar -0,092 menyatakan setiap terdapat penambahan atau peningkatan satuan skor subjek pada variabel efikasi diri, maka akan terjadi peningkatan work-life balance sebesar 0,092.

Rangkuman hasil uji hipotesis dalam penelitian ini dihasilkan bahwa hipotesis mayor dan hipotesis minor dalam penelitian ini dapat diterima. Rangkuman hasil uji terhadap hipotesis mayor dan hipotesis minor pada penelitian ini dapat dilihat pada tabel 8 (rangkuman hasil uji hipotesis penelitian. terlampir).

\section{PEMBAHASAN DAN KESIMPULAN}

\section{Pembahasan}

Berdasarkan hasil penelitian yang telah diuji menggunakan metode analisis berganda dapat diketahui bahwa pengujian hipotesis menunjukkan adanya peran yang signifikan antara variabel dukungan sosial keluarga dan efikasi diri dalam meningkatkan work-life balance pada mahasiswa yang bekerja di Denpasar. Hal ini dapat dilihat dari nilai koefisien regresi (R) pada penelitian ini sebesar 0,812 dan nilai $F$ hitung sebesar 152,152 dengan taraf signifikansi sebesar $0,000 \quad(p<0,05)$ menunjukkan bahwa dukungan sosial keluarga dan efikasi diri secara bersama- sama berperan terhadap work-life balance.

Koefisien determinasi sebesar 0,660 menunjukkan bahwa kedua variabel bebas yakni dukungan sosial keluarga dan efikasi diri memberikan sumbangan efektif sebesar $66 \%$ terhadap variabel tergantung work-life balance. Maka berdasarkan hasil tersebut dapat ditarik kesimpulan bahwa dukungan sosial keluarga dan efikasi diri menentukan $66 \%$ tingkat work-life balance yang dimiliki oleh mahasiswa yang bekerja di Denpasar, sedangkan 34\% dipengaruhi oleh variabel atau faktor lain yang tidak diteliti dalam penelitian ini.

Pada koefisien beta terstandarisasi diketahui bahwa dukungan sosial keluarga dan efikasi diri secara mandiri memiliki peran terhadap work-life balance. Variabel dukungan sosial memiliki koefisien beta terstandarisasi sebesar 0,863 dengan nilai t sebesar 17,217 dan memiliki taraf signifikansi sebesar $0,000(\mathrm{p}<0,05)$ yang menunjukkan bahwa dukungan sosial keluarga berpengaruh secara signifikan dalam meningkatkan work-life balance. Variabel efikasi diri memiliki koefisien beta terstandarisasi sebesar -0,079 dengan nilai $\mathrm{t}$ sebesar 1,683 dan memiliki taraf signifikansi sebesar 0,047 $(\mathrm{p}<0,05)$ yang menunjukkan bahwa efikasi diri berpengaruh secara signifikan dalam meningkatkan work-life balance.

Berdasarkan hasil koefisien beta terstandarisasi, dapat diketahui bahwa variabel bebas yang memiliki pengaruh paling tinggi terhadap work-life balance adalah dukungan sosial keluarga. Dukungan sosial keluarga lebih berpengaruh terhadap work-life balance dibandingkan dengan efikasi diri karena pada masa remaja khususnya remaja akhir pemberian dukungan sosial yang diberikan keluarga berupa pemberian informasi, saran, kondisi sosial ekonomi, penyediaan sarana dan prasarana sangat dibutuhkan bagi remaja untuk membantu dalam menyeimbangkan kehidupannya (Widanarti \& Indarti, 2002). Selain dukungan berupa pemberian saran dan informasi, bentuk interaksi dan model peran keluarga memiliki pengaruh yang besar terhadap sikap anak dalam bekerja (Loughling \& Barlin, 2001).

Mahasiswa yang memiliki dukungan sosial yang baik memiliki rasa percaya diri yang baik dalam menyelesaikan tugas yang dihadapi, mengurangi stres dan mencegah timbulnya depresi (Friedman, 2009). Kemampuan dalam menyelesaikan tugas dengan baik merupakan sebuah syarat yang harus dipenuhi ketika seseorang berada dalam 
lingkungan kerja. Individu dengan dukungan sosial keluarga yang rendah akan menimbulkan efek negatif seperti stres dan kemampuan resiliensi yang rendah terhadap suatu masalah (Wilks \& Spivey, 2010).

Kesejahteraan merupakan salah satu aspek penting dalam mencapai keseimbangan dalam kehidupan seseorang karena dapat mengembangkan sikap positif dalam diri individu. Hasil penelitian yang dilakukan oleh Shteigman dan Abraham pada tahun 2015 menyebutkan bahwa lingkungan kerja dan dukungan sosial mampu memberikan energi positif dalam menyeimbangkan kehidupan dan kesejahteraan secara psikologis.

Pada deskripsi data penelitian, variabel dukungan sosial memiliki mean teoretis sebsar 42,5 dan mean empiris sebesar 50,80 (mean empiris > mean teoretis) yang menunjukkan bahwa mahasiswa yang bekerja di Denpasar memiliki tingkat dukungan sosial yang tinggi. Hasil kategorisasi data dukungan sosial keluarga menunjukkan bahywa mayoritas subjek penelitian memiliki tingkat dukungan sosial kategori tinggi sebanyak 121 orang $(75,6 \%)$. Tingginya tingkat dukungan sosial yang dimiliki oleh mahasiswa membuktikan bahwa dukungan baik dalam bentuk emosional, instrumental, informatif dan evaluatif yang diberikan oleh anggota keluarga sudah mampu memenuhi kebutuhan mahasiswa dalam mencapai work-life balance. Hal tersebut sejalan dengan penelitian Brough, Siu, O’Driscoll, \& Timms (2015) bahwa pemberian dukungan mampu meningkatkan keyakinan individu dalam menjalankan pekerjaan dan meningkatkan kepuasan individu terhadap pekerjaan dan keluarga.

Dukungan sosial memiliki manfaat yang efektif bagi individu ketika mengalami kesulitan. Menjalani peran yang berlebih atau role-overload menyebabkan bertambahnya beban dan tanggung jawab yang dimiliki oleh individu. Individu yang memasuki usia remaja khususnya remaja akhir akan lebih mendengarkan informasi dan nasehat yang diberikan oleh teman sebaya dibanding keluarga (Santrock, 2007), sehingga diperlukan komunikasi yang efektif serta pola asuh yang baik seperti otoritatif agar orangtua mampu menyalurkan dukungan untuk membantu menyeimbangkan kehidupan remaja.

Sama halnya dengan dukungan sosial keluarga, efikasi juga berpengaruh terhadap tingkat work-life balance mahasiswa yang bekerja, namun dengan nilai koefisien beta terstandarisasi lebih kecil dibanding dukungan sosial keluarga. Efikasi diri mampu memengaruhi pilihan karir seseorang yang ditentukan melalui eksplorasi karir sehingga menyebabkan individu memiliki tingkat ketekunan yang lebih tinggi ketika menghadapi masalah atau rintangan (Betz, 2004).

Pada deskripsi data penelitian, variabel efikasi diri memiliki mean teoretis sebesar 42,5 dan mean empiris sebesar 74,67 (mean empiris > mean teoretis) yang menunjukkan bahwa subjek dalam penelitian ini memiliki tingkat efikasi diri yang baik. Hasil kategorisasi data penelitian menunjukkan bahwa mayoritas subjek penelitian memiliki taraf efikasi diri yang tinggi yakni sebanyak 119 orang $(74,4 \%)$. Tingginya tingkat efikasi diri yang dimiliki oleh subjek dalam penelitian ini dapat dipengaruhi oleh kemampuan individu dalam beradaptasi terhadap situasi dan masalah baru yang dialami. Individu dengan sikap efikasi diri yang baik mampu menunjukkan kepuasan kerja secara menyeluruh untuk mencapai keseimbangan kehidupan dan kerja atau work- life balance (Permarupan dkk, 2013). Semakin tinggi tingkat efikasi diri seseorang maka semakin tinggi tingkat work-life balance individu semakin baik. Individu dengan efikasi diri yang baik juga lebih mudah dalam menyesuaikan diri terhadap suatu masalah dengan sikap realistis dan berpikir secara rasional untuk menyelesaikan sebuah masalah, seperti mampu bertanggung jawab dalam setiap pekerjaan atau kegiatan yang dilakukan, melihat masalah sebagai alasan untuk tetap semangat dan berusaha keras untuk mencapai hasil yang diinginkan, serta percaya akan kemampuan yang dimiliki (Lauster, 1998).

Work-life balance merupakan keseimbangan yang diperoleh dalam membagi waktu antara kehidupan pribadi dan pekerjaan untuk mencapai kehidupan yang sejahtera. Untuk menghindari timbulnya konflik, kehidupan pribadi dan pekerjaan harus berada pada posisi yang seimbang. Pada deskripsi data penelitian diperoleh hasil bahwa work-life balance memiliki mean teoretis sebesar 65 dan mean empiris sebesar 74,67, serta nilai $t$ sebesar 24,287 $(\mathrm{p}=0,000)$. Berdasarkan penyebaran frekuensi diperoleh hasil bahwa sebanyak 134 mahasiswa yang bekerja di Denpasar dengan persentase 83,8\% memiliki tingkat work-life balance dengan kategori sedang, hal ini menunjukkan bahwa mahasiswa yang bekerja di Denpasar belum optimal dikarenakan mahasiswa masih memiliki potensi memiliki konflik antara karir dan kehidupan pribadi. Sejalan dengan penelitian Rahmawati (2016), bahwa semakin baik tingkat work-life balance pada individu maka semakin rendah konflik yang dihadapi oleh individu tersebut. Keberadaan konflik antara karir dan kehidupan pribadi sangat berpengaruh secara signifikan terhadap tingkat work- life balance seseorang karena dapat menghambat kesempatan dalam kesuksesan berkarir dan keberhasilan dalam menjalankan peran (Lockwood, 2003).

Setelah melalui prosedur penelitian dan analisis data, maka tujuan dari penelitian ini telah terpenuhi yaitu untuk mengetahui peran dukungan sosial keluarga dan efikasi diri terhadap tingkat work-life balance mahasiswa yang bekerja di Denpasar. Walaupun demikian, penelitian ini masih memiliki beberapa kelemahan yakni, variabel yang digunakan dalam penelitian ini hanya terbatas pada variabel dukungan sosial keluarga dan efikasi diri.

\section{Kesimpulan dan Saran}

Kesimpulan

Kesimpulan yang diperoleh berdasarkan hasil analisis data yang telah dilakukan adalah sebagai berikut :

a. Dukungan sosial keluarga dan efikasi diri secara bersama-sama berperan dalam meningkatkan work-life balance pada mahasiswa yang bekerja di Denpasar.

b. Semakin tinggi tingkat dukungan sosial keluarga dan efikasi diri maka tingkat work-life balance pada mahasiswa yang bekerja semakin meningkat. Semakin rendah tingkat dukungan sosial keluarga dan efikasi 
diri maka tingkat work-life balance pada mahasiswa yang bekerja juga akan semakin menurun.

c. Dukungan sosial keluarga memiliki peran yang signifikan dalam meningkatkan work-life balance pada mahasiswa yang bekerja di Denpasar.

d. Efikasi diri memiliki peran yang signifikan dalam meningkatkan work-life balance pada mahasiswa yang bekerja di Denpasar.

e. Tingkat work-life balance yang dimiliki oleh mahasiswa yang bekerja di Denpasar tergolong sedang.

f. Dukungan sosial keluarga yang dimiliki oleh mahasiswa yang bekerja di Denpasar tergolong tinggi.

g. Efikasi diri yang dimiliki oleh mahasiswa yang bekerja di Denpasar tergolong tinggi.

$\underline{\text { Saran }}$

Berdasarkan hasil penelitian yang telah dilakukan, maka dapat disampaikan saran praktis bagi pihak-pihak berikut ini :

\section{Bagi Keluarga}

Keluarga sebaiknya memberikan motivasi kepada mahasiswa yang menjalani kuliah sambil bekerja agar dapat menjalani kehidupan yang sejahtera. Ketika mahasiswa memilih bekerja karena alasan membantu keadaan ekonomi orangtua, maka orangtua maupun keluarga diharapkan memberikan dukungan dan kesempatan serta meyakini bahwa mahasiswa dapat melakukan aktivitasnya dengan baik.

Bagi Mahasiswa

Mahasiswa diharapkan untuk terbuka dalam mengemukakan pendapat maupun menceritakan masalah pada orang lain sekaligus menerima umpan balik atau saran yang diberikan khususnya oleh keluarga sebagai wujud dari kepedulian bagi anggota keluarga agar mampu membantu menemukan jalan keluar dari masalah yang dihadapi baik di lingkungan kerja maupun perkuliahan.

\section{Bagi Institusi Pendidikan}

Institusi pendidikan terutama perguruan tinggi yang menerapkan pembelajaran berbasis kerja atau karir diharapkan mampu memberikan fasilitas terhadap mahasiswa yang sedang kuliah sambil bekerja atau ingin menjalani kuliah sambil bekerja. Fasilitas tersebut dapat berupa program pendidikan yang kooperatif berupa magang berbayar, agar setelah lulus nanti mahasiswa memiliki pengalaman dan bekal dalam mencari pekerjaan.

\section{Bagi Perusahaan atau Organisasi}

Perusahaan atau Organisasi diharapkan untuk mengkaji program perusahaan untuk merancang program yang dapat membantu karyawan khususnya mahasiswa yang bekerja dalam mencapai keseimbangan work-life balance. Perusahaan maupun organisasi juga sebaiknya memberikan fasilitas atau insentif yang menunjang kesejahteraan karyawan. Kemudian, perusahaan maupun orgnaisasi diharapkan mampu memaksimalkan penerapan pengaturan jam kerja yang fleksibel bagi mahasiswa agar dapat menjalani kuliah sambil bekerja. Perusahaan dan organisasi diharapkan melakukan survey internal mengenai keseimbangan kehidupan-kerja karyawan agar dapat memantau kondisi karyawan dari aspek pribadinya.

\section{DAFTAR PUSTAKA}

Bandura, A. (1986). Social learning theory. Englewood Cliffs, NJ: Prentice-Hall.

Betz ,N. E. (2004). Contributions of efikasi diri theory to career counseling: a personal perspective. Career Dev Q, 52, 340-353. Diakses dari https://onlinelibrary.wiley.com/doi/abs/10.1002/j.21610045.2004.tb00950.x pada 13 Juni 2018.

Brough, P., Siu, O. L., Kalliath, T., \& Timms, C. (2015). Crosscultural impact of work-life balance on health and work outcomes. L. Luo \& G. L. Cooper (Eds). Handbook of research on Work-life Balance in Asia (hal. 295-314).

Field, A. (2009). Discovering statistics using spss ed. 3. London: SAGE Publication.

Friedman, S. (2009). Top ten negotiating tactics every meeting manager should know. New Jersey: Pearson.

Frone, M. R., Russell, M., \& Cooper, M. L. (1992). Prevelence of work-family conflict : Are work and family boundaries asymmetrically permeable? Diakses dari https://www.researchgate.net/publication/229480373 pada 31 Oktober 2017.

Ghozali, I. (2005). Aplikasi analisis multivariate dengan program spss. Semarang: Badan Penerbit Universitas Diponegoro.

Greenhaus, J. H., Collins, K. M \& Shaw, J. (2003). The relation between work- family balance and quality of life. Journal of Vacational Behavior, 63, 510-531. Diakses dari https://www.sciencedirect.com/science/article/abs/pii/S000 1879102000428 pada 17 Juli 2017.

Gropel, P., \& Kuhl, J. (2008). Work-life balance and subjective well being: the mediating role of need fulfillment. British Journal of Psychology, 100(2), 75-365. doi: 10.1348/000712608X337797.Diakses dari https://www.researchgate.net/publication/23185193 pada 18 September 2017.

House, J. S. (1987). Social support and social structure. Forum Sosiologi, 2(1), 135-146. Diakses dari https://link.springer.com/article/10.1007\%2FBF01107897 pada 17 Juli 2017.

Kaplan, H. I., Sadock B. J., \& Grebb J. A. (2010). Sinopsis psikiatri ilmu pengetahuan perilaku psikiatri klinis. Tangerang: Binarupa Aksara.

Lauster, P. (1988). Tes kepribadian (Gulo, D. H. Terjemahan). Jakarta: PT. Gramedia Pustaka Utama.

Lockwood, N. R. (2003). Work-life balance: challenge and solutions. USA: SHRM Research Department.

Loughlin, C. \& Barling, J. (2001). Young worker's work values, attitudes, and behaviours. Jurnal Psikologi Industri dan Organisasi, 74, 543-558. Diunduh dari https://www.researchgate.net/publication/247826653 pada 22 Juli 2018

Purwati. (2016). Pengaruh keseimbangan kehidupan kerja (work-life balance) terhadap beban kerja (work load) divisi penjualan di PT. ULAM TIBA HALIM (MARIMAS) Cabang Sidoarjo. Skripsi tidak dipublikasikan. Diakses dari https://etheses.uinmalang.ac.id/3693/1/12410070.pdf pada 12 Mei 2017.

Permarupan, P. Y., Saufi, R. A., \& Mahmud, R. (2013). The relationship between career development and talent development practices : towards employee quality of worklife balance. International Journal of Multidisciplinary Thought. 3(2), 463-475. Diakses dari https://www.researchgate.net/publication/259603735 pada 3 April 2018

Rahmawati, A. (2016). Pengaruh keseimbangan kehidupan kerja (work life balance) dan kepuasan kerja terhadap loyalitas guru smk swasta di kecamatan cakung jakarta timur. Jurnal 
Manajemen Pendidikan, 7(1). Diakses dari

http://journal.unj.ac.id/unj/index.php/jmp/article/view/1827 pada 4 Januari 2018.

Santrock, J.W. (2007b). Perkembangan remaja jilid 2 (11thed.). Jakarta Penerbit Erlangga. Sugiyono. (2014). Metode penelitian pendidikan pendekatan kuantitatif, kualitatif dan R\&D.

Bandung: Alfabeta.

Triwijayanti, D. A. K. (2017). Faktor-faktor yang memengaruhi tingkat work-life balance pada mahasiswa yang bekerja di Denpasar. Naskah tidak dipublikasikan. Program Studi Psikologi, Fakultas Kedokteran, Universitas Udayana.

Twenge, J. M., Campbell, S. M., Hoffman, B. J., \& Lance, C. E. (2010). Generational differences in work values: leisure and extrinsic values increasing, social and intrinsic values decreasing. Diakses dari http://journals.sagepub.com/doi/abs/10.1177/01492063093 52246 pada 31 Mei 2018.
Yustrianthe, R. H. (2008). Pengaruh flexible work arrangement terhadap role conflict, role overload, reduced personal accomplishment, job satisfaction, dan intention to stay. Jurnal Bisnis dan Akuntansi, 10(3), 127-138. Diakses dari http://www.e-jurnal.com/ pada 18 Juli 2017.

Widanarti, N., \& Indati, A. (2002). Hubungan antara dukungan sosial keluarga dengan efikasi diri pada remaja di SMU Negeri 9 Yogyakarta. Jurnal Psikologi Universitas Gajah Mada Yogyakarta, 9(2), 112-123. Diunduh dari

https://jurnal.ugm.ac.id/jpsi/article/download/7019/5471 pada 24 Juni 2017.

Wilks, S.E., \& Spivey, C.A. (2010). Resilience in undergraduate social work students: social support and adjustment to academic stress. Social Work Education, 29(3), 276-288. doi:10.1080/02615470902912243. Diunduh dari www.tandfonline.com/doi/abs/10.1080/0261547090291224 3 pada 29 Juli 2018. 


\section{LAMPIRAN}

Tabel 1

Deskripsi Data Penelitian

\begin{tabular}{|c|c|c|c|c|c|c|c|c|}
\hline Variabel & $\mathrm{N}$ & $\begin{array}{c}\text { Mean } \\
\text { Teoretis }\end{array}$ & $\begin{array}{c}\text { Mean } \\
\text { Empiris }\end{array}$ & $\begin{array}{c}\text { Std. } \\
\text { Deviasi } \\
\text { Teoretis }\end{array}$ & $\begin{array}{c}\text { Std. } \\
\text { Deviasi } \\
\text { Empiris }\end{array}$ & $\begin{array}{l}\text { Sebaran } \\
\text { Teoretis }\end{array}$ & $\begin{array}{l}\text { Sebaran } \\
\text { Empiris }\end{array}$ & Nilai T \\
\hline DSK & 160 & 42,5 & 50,80 & 8,5 & 3,555 & $17-68$ & $42-61$ & $\begin{array}{l}29,531 \\
(p=0,000)\end{array}$ \\
\hline $\mathrm{SE}$ & 160 & 42,5 & 51,91 & 8,5 & 4,289 & $17-68$ & $45-67$ & $\begin{array}{l}27,760 \\
(p=0,000)\end{array}$ \\
\hline WLB & 160 & 65 & 74,67 & 13 & 5,039 & 26- 104 & $63-87$ & $\begin{array}{l}24,287 \\
(p=0,000)\end{array}$ \\
\hline
\end{tabular}

Tabel 2

Uji Normalitas Data Penelitian

\begin{tabular}{cccc}
\hline Variabel & $\begin{array}{c}\text { Shapiro- } \\
\text { Wilk }\end{array}$ & Sig. & Kesimpulan \\
\hline Work-life Balance & 0,989 & 0,242 & Data Normal \\
Dukungan sosial keluarga & 0,948 & 0,000 & Data Tidak Normal \\
Efikasi diri & 0,882 & 0,000 & Data Tidak Normal \\
\hline
\end{tabular}

Tabel 3

Uji Linearitas Data Penelitian

Linearity $\begin{gathered}\text { Deviation } \\ \text { from Linearity }\end{gathered} \quad$ Kesimpulan

\begin{tabular}{llll}
\hline Work-life Balance * Dukungan Sosial Keluarga & 0,000 & 0,855 & Data Linier \\
Work-life Balance * Efikasi diri & 0,000 & 0,464 & Data Linier \\
\hline
\end{tabular}

Tabel 4

Uji Multikolinearitas Data Penelitian

\begin{tabular}{lc|cc}
\hline \multirow{2}{*}{ Model } & \multicolumn{2}{c}{ Collienarity Statistics } & \multirow{2}{*}{ Keterangan } \\
\cline { 2 - 3 } & Tolerance & VIF & \\
\hline Dukungan Sosial Keluarga & 0,996 & 1,004 & Tidak ada multikolinearitas \\
Efikasi diri & 0,996 & 1,004 & Tidak ada multikolinearitas \\
\hline
\end{tabular}


Tabel 5

Uji Regresi Berganda

\begin{tabular}{cccc}
\hline $\mathbf{R}$ & R Square & Adjusted R Square & Std. Error of the Estimate \\
\hline 0,812 & 0,660 & 0,655 & 2,95829 \\
\hline
\end{tabular}

Tabel 6

Uji Regresi Berganda Signifikansi Nilai F

\begin{tabular}{cccccc}
\hline & Sum of Square & $d f$ & Mean Square & F & Sig. \\
\hline Regression & 2663,118 & 2 & 1331,559 & 152,152 & 0,000 \\
Residual & 1373,982 & 157 & 8,751 & & \\
\hline Total & $\mathbf{4 0 3 7 , 1 0 0}$ & $\mathbf{1 5 9}$ & & & \\
\hline
\end{tabular}

Tabel 7

Hasil uji regresi berganda Nilai Koefisien Beta dan Nilai T Variabel Dukungan Sosial Keluarga dan Efikasi diri terhadap Worklife Balance

\begin{tabular}{|c|c|c|c|c|c|}
\hline \multirow[t]{2}{*}{ Model } & $\begin{array}{c}\text { Unstandardized } \\
\text { Coefficients }\end{array}$ & \multicolumn{2}{|c|}{$\begin{array}{l}\text { Standardized } \\
\text { Coefficients }\end{array}$} & \multirow[t]{2}{*}{$\mathrm{t}$. } & \multirow[t]{2}{*}{ Sig. } \\
\hline & B & Std. Enror & Beta & & \\
\hline (Constant) & 21,627 & 4,548 & & 4,755 & 0,000 \\
\hline Dukungan sosial keluarga & 1,139 & 0,066 & 0,803 & 17,217 & 0,000 \\
\hline Efikasi diri & $-0,092$ & 0,055 & $-0,079$ & $-1,683$ & 0,047 \\
\hline
\end{tabular}

Tabel 8

Rangkuman Hasil Uji Hipotesis Penelitian

\begin{tabular}{|c|c|c|}
\hline No. & Hipotesis & Hasil \\
\hline & $\begin{array}{l}\text { Efikasi diri dan Dukungan Sosial Keluarga berperan } \\
\text { dalam meningkatkan Work-Life Balance Mahasiswa yang } \\
\text { bekerja di Denpasar. }\end{array}$ & $\mathrm{H}_{0}$ Ditolak \\
\hline \multirow[t]{2}{*}{2} & $\begin{array}{l}\text { Hipotesis Minor } \\
\text { a Efikasi diri berperan dalam meningkatkan Work-Life } \\
\text { Balance Mahasiswa yang bekerja di Denpasar. }\end{array}$ & $\begin{array}{l}\mathrm{H}_{0} \text { Ditolak } \\
\mathrm{H}_{\mathrm{a}} \text { Diterima }\end{array}$ \\
\hline & $\begin{array}{l}\text { b. Dukungan Sosial Keluarga berperan dalam } \\
\text { meningkatkan Work-Life Balance Mahasiswa yang } \\
\text { bekerja di Denpasar. }\end{array}$ & $\begin{array}{l}\mathrm{H}_{0} \text { Ditolak } \\
\mathrm{H}_{\mathrm{a}} \text { Diterima }\end{array}$ \\
\hline
\end{tabular}

